\title{
Teacher Cognition and Grammar Teaching in a Japanese High School
}

\author{
Masateru Nishimuro \\ Kwansei Gakuin Senior High School, Nishinomiya \\ Simon Borg \\ School of Education, University of Leeds, UK
}

In this paper we examine the relationship between teachers' practices and cognitions in teaching grammar. A qualitative analysis of classroom observations and interviews with three experienced Japanese teachers of English highlights both the key features of these teachers' pedagogies in teaching grammar and the cognitions underpinning their work. Their practices were characterized by detailed teacherfronted explanations of grammatical forms, metalinguistic explicitness, and the use of the L1. These practices were underpinned by the teachers' beliefs about the value of grammar, though there was little evidence that the teachers' pedagogical choices were consciously informed by current theoretical or methodological ideas in the field of L2 teaching. Rather, the approach to grammar adopted by the teachers had a strong experiential basis and was influenced by a desire to motivate and promote the well-being of their students as well as by contextual factors such as learners and colleagues.

近年、教師認知の観点からCommunicative Language Teaching (CLT) の導入に関わる考察が 多くなされているが、本稿は日本の英語教育の主な関心であり続ける文法指導にその焦点をあ てた。日本の高校に勤める経験豊かな 3 人の日本人英語教師各々に授業観察と観察前後の个 ンタビューからなる質的調査を実施し、文法指導の実践とその実践の根拠となる彼らの教育的 信条や認知との関係性を探った。日本語を用いた教師主導の文法形式の説明とメ夕言語学的明 示性に象徵された彼らの実践は、文法指導に価值をおく彼らの信条が根拠となつていたが、そ の指導法を採用する判断においては第二言語(外国語)教育分野の理論、方法論を基にしたと いう根拠はほぼなかった。むしろ彼らの指導法は、教師自身の学習・指導経験が大きな基礎を

JALT Journal, Vol. 35, No. 1, May 2013 
なし、学習者の動機を高め彼らに人間として良く成長してほしいという願い、学習者や同僚とい ったコンテクスト要因に影響されていた。

7 eacher cognition-defined as "what teachers know, believe, and think" (Borg, 2003, p. 81) - has in the last 15 years become a major

1 area of research in the field of L2 teaching. This work has provided insights into the mental lives of teachers as well as into how cognition and context interact in shaping the instructional decisions teachers make. As a result of this research, it is widely acknowledged that it is not possible to understand what teachers do without also understanding their cognitions. Various domains of L2 teaching have been examined from a teacher cognition perspective (Borg, 2006); amongst these, grammar teaching, the focus of this paper, has received the most attention.

\section{Teacher Cognition and Grammar Teaching}

Research into grammar learning has a long history (see the comprehensive review in Ellis, 2008) and while it is now acknowledged that some degree of formal instruction of grammar supports the L2 learning process (Nassaji \& Fotos, 2011), precise and universally applicable answers to many of the questions teachers face in teaching grammar remain unavailable, as Ellis (2006) explains. Examples of such questions are whether grammar should be approached deductively or inductively (Gollin, 1998), whether grammar is best taught integratively or as a separate component of the foreign language learning syllabus (Borg \& Burns, 2008), and whether knowledge of grammatical terminology enhances learning. Teachers also face questions about the nature of the grammar practice activities they should employ (Nitta \& Gardner, 2005) and about the medium (i.e., L1 or L2) through which explicit grammar work is best handled. To complement research on the learning of L2 grammar and in response to the lack of definitive guidance it has provided to the above issues, a teacher cognition perspective has more recently been applied to the study of L2 grammar teaching.

Several studies in a range of international contexts illustrate this perspective. For example, drawing on a number of studies in Hong Kong, Andrews (2007) found that teachers' own knowledge about grammar plays a significant role in the instructional decisions they make when teaching it, while Borg (2001), working with a teacher in Malta, showed that it was not only teachers' actual knowledge of grammar that influenced their teaching, but also how confident they felt about this knowledge (less confident teachers 
were found to minimize explicit grammar work). In relation to whether grammar is best taught separately or integrated with other language skills, Borg and Burns (2008) reported that $84 \%$ of an international sample of 176 teachers disagreed that "grammar should be taught separately" from other skills (p. 466). This body of research has also shown that how teachers approach grammar will be shaped by the interaction of their beliefs about language learning, their views about their learners' needs and wants, and contextual factors such as the availability of time (e.g., Farrell \& Lim, 2005). As a result of such interactions, what teachers do in the classroom may not necessarily reflect their beliefs about how grammar should be taught (see, e.g., Basturkmen, Loewen, \& Ellis, 2004). It is therefore essential in studies of teacher cognition to examine not only teachers' theoretical beliefs (e.g., Jean \& Simard, 2011; Schulz, 1996) but also how these are mediated in practice by the contexts in which teachers work (e.g., Pahissa \& Tragant, 2009, which shows how context impacts on the teaching of L2 grammar).

There has been little specific qualitative research into teacher cognition and grammar teaching in Japan. There have been, however, a number of studies into teachers' implementation of communicative principles (e.g., Gorsuch, 2000, 2001; Kikuchi \& Browne, 2009; Nishino, 2008, 2011; Sakui, 2004, 2007; Sato \& Kleinsasser, 2004; Taguchi, 2005). These are relevant to the current study in that they provide evidence that teachers of English in Japan continue to value explicit grammar work despite policy and teacher training initiatives aimed at increasing the frequency of communicative activities in the language classroom. For example, Gorsuch, through a survey of 876 Japanese teachers of English, concluded that while they mildly approved of communicative activities, there were also "potent impediments working against teachers actually using such activities in their classrooms" (Gorsuch, 2001, Conclusion section, para. 1). A recent analysis by Underwood (2012) highlighted a similar phenomenon, although he also questioned the extent to which teachers' perceptions of some of these impediments were accurate. Via a questionnaire and focus group interviews with 16 senior high school teachers of English in Japan, this study suggested that the teachers held positive beliefs about the integration of grammar with communication-oriented teaching. These beliefs, though, were tempered by concerns (and misconceptions, the author suggested) about the negative impact that a communicative approach to grammar would have on students' performance on university entrance examinations. Many teachers in this study thus seemed to believe that such examinations emphasized discrete-point grammatical knowledge much more than an analysis of the examinations themselves would suggest. 
Given such insights and the continuing prominence of grammar teaching in debates about English language teaching in Japan, further qualitative research in this context is needed to develop deeper understandings of both what teachers do and the reasons behind their pedagogical decisions in relation to grammar. The study we report here responds to this need.

Note: For the sake of conciseness, and corresponding to such factors as practices and behaviours, any identifiable teacher knowledge or awareness is herein referred to as a cognition (plural: cognitions).

\section{The Study}

\section{Research Questions}

Informed by the literature discussed above, this study examined the following questions:

1. What practices characterize the grammar teaching of three teachers of English in a Japanese high school?

2. What cognitions underpinned these practices?

3. What contextual factors shaped the teachers' work?

Grammar teaching here was defined as instruction which focuses on the morpho-syntactic features of English.

\section{Context}

This study took place in a private boys' high school in a large Japanese urban area. Approximately $90 \%$ of the school's graduates enter the university with which it is affiliated by way of self-recommendation (based on their academic and extra-curricular achievement reports for the previous 3 years) rather than via a more customary high-stakes entrance examination. This is significant here because university entrance examinations-a source of pressure the teachers in this study were free from-have been cited in studies of Japanese teachers of English as a major constraint on their practice (e.g., Gorsuch, 2001). There were approximately 900 students in the school together with 16 Japanese English teachers (seven of whom worked part-time) and three native-speaking English Assistant Language Teachers. The school followed the national curriculum and enjoyed a good academic reputation in the region. The textbooks used for teaching English provided both grammar and skills-oriented work and were locally written, government approved, and chosen by the English department in the school. They were in Japanese and contained some pair work and group work activities after every five lessons. 


\section{Participants}

The participants were three experienced male Japanese EFL teachers. Two criteria determined their choice: first, when contacted prior to the study, they confirmed that grammar teaching was a central facet of their work; and second, they were interested in contributing to the study. Table 1 describes the participants (using pseudonyms) and provides information about the lessons they were observed teaching in this study. As this shows, in Mr. Tanaka's and Mr. Endo's classes, teaching grammar was the main focus of the lessons, while grammar was a secondary focus in Mr. Matsuda's reading lessons. All three teachers used officially approved coursebooks but were not obliged to follow any particular teaching methodology.

Table 1. Participants in the Study

\begin{tabular}{|l|c|c|l|}
\hline Pseudonym & Age & $\begin{array}{c}\text { Years of } \\
\text { teaching } \\
\text { experience }\end{array}$ & \multicolumn{1}{c|}{ Lessons observed } \\
\hline Matsuda & 50 & 25 & Reading for Year 12 (45 students) \\
\hline Tanaka & 50 & 27 & $\begin{array}{l}\text { English II*: Level-based English writ- } \\
\text { ing for Year } 11 \\
\text { <To infinitive> (20 students) }\end{array}$ \\
\hline Endo & 47 & 25 & $\begin{array}{l}\text { English } I^{*} \text { : English grammar for Year } \\
10,<\text { will/be going to, perfect tense> } \\
(45 \text { students })\end{array}$ \\
\hline
\end{tabular}

*In this school, English I is taught to Year 10 students and is divided into two subjects: Reading and English Grammar. English II is taught to Year 11 students and is divided into Reading and level-based English writing.

\section{Data Collection}

The study employed a qualitative methodology, which was appropriate given our goal of understanding practices and cognitions in some depth and from teachers' own perspectives. Our choice acknowledged the position that "studies which employ qualitative strategies to explore language teachers' actual practices and beliefs will be more productive (than, for example, questionnaires about what teachers do and believe) in advancing our understanding of the complex relationships between these phenomena" (Phipps \& Borg, 2009, p. 388). A case study approach (Duff, 2008) was employed, as 
this allowed us to examine each teacher's practices in detail and individually before moving on to consider the findings collectively. For each case, there were three phases of data collection. First, each teacher participated in a pre-observation interview. They were then observed teaching two regular lessons of 45 minutes before finally participating in a post-observation interview. All data were collected in the 2010-11 academic year.

\section{Pre-Observation Interviews}

The pre-observation interview aimed to elicit background information about each participant that was felt to be relevant in understanding their approach to grammar teaching. The issues covered were the teachers' educational background, experience of learning and teaching English or grammar, self-perceptions of their English proficiency and knowledge about grammar, school culture, and their general views about ELT and grammar teaching. Some of the questions were adapted from those in existing research on teacher cognition and grammar teaching, namely Borg (1998), Borg and Burns (2008), and Schulz (2001). The interviews were conducted in Japanese, audio recorded, and lasted on average 90 minutes. The semistructured format (for a discussion see, for example, Dörnyei, 2007) meant that while questions were set in advance, there was flexibility for additional questions to be asked in response to issues emerging in the course of the conversation. Appendix A gives examples of the pre-observation interview questions.

\section{Classroom Observations}

As noted above, each teacher was observed teaching two regular lessons of 45 minutes each. As Borg (2006) suggests, classroom observation "has a central role to play in the study of language teacher cognition by providing a concrete descriptive basis in relation to what teachers know" (p. 231). Thus, the observations provided direct evidence of teachers' practices in teaching grammar. The observations took place in a normal classroom setting, and the observer was a nonparticipant in the lesson (i.e., observing as a researcher and not interacting with the teacher or students). A video camera at the back of the classroom recorded each lesson and field notes were also made. All lessons were conducted in Japanese and the episodes presented here are English translations. 


\section{Post-Observation Stimulated Recall Interviews}

Data collected through the observations were analysed in order to generate questions for a second interview with each teacher. This was a stimulated recall interview using transcribed extracts of the observed lessons and materials (i.e., coursebooks and handouts) to prompt a discussion of the teachers' approach to grammar and of factors shaping it (for recent examples of the use of stimulated recall interviews in the study of language teacher cognition, see Kanno \& Stuart, 2011; Kim, 2011; Kuzborska, 2011). Participants were asked to comment on aspects of their teaching and, in line with the purposes of qualitative stimulated recall interviews, they were given "the opportunity to verbalize their thinking, in a relatively free and open-ended manner" (Borg, 2006, p. 210). These interviews were conducted (again, in Japanese) as soon as possible after the observed lesson. They were recorded and lasted on average 90 minutes. Appendix B lists examples of the questions asked during the post-observation interviews.

Overall, the database for this study consisted of approximately 9 hours of recorded interview data and 4.5 hours of recorded classroom observation data, together with the materials used in the lessons. All phases of the study were informed by an awareness of ethical principles in educational research, such as informed consent and confidentiality (see, for example, Denscombe, 2002).

\section{Data Analysis}

All recorded data were transcribed, then translated into English by the first author. The pre-observation interviews were analysed qualitatively and profiles of each teacher developed using the background information provided in those interviews. The observational data were then analysed for each teacher to identify key instructional episodes (Borg, 1998) in their work. A key instructional episode was defined as one that illustrated an aspect of the teacher's work in teaching grammar. In identifying such episodes, key themes in the literature on grammar teaching, highlighted earlier, provided a set of categories for describing practice. For example, observations were analysed for evidence of the ways in which teachers introduced and practised grammar and of the extent to which the L1 and grammatical terminology were used. As a result of this analysis, the key characteristics of each teacher's work in teaching grammar were identified. The post-observation interviews were analysed according to established principles for working with qualitative data (see, e.g., Newby, 2010). Through repeated readings 
of the data, key themes in the teachers' rationales for their practices were identified and categorized, following a largely inductive process (i.e., where categories emerged from the data) although factors highlighted in previous research on teacher cognition and grammar teaching also provided some direction to the analysis. Insights from the pre-observation interviews were also drawn on here in constructing, for each teacher, an account of how he taught grammar and why he did so in particular ways. These individual accounts were then compared and key crosscutting themes in them identified.

\section{Findings}

In the curriculum followed by the teachers, grammar was addressed through 2 hours of designated grammar lessons each week. The teachers did not express any opposition to this approach and shared the belief that grammar instruction plays a vital role in an EFL environment such as Japan. While they acknowledged the need for their students to learn how to use English communicatively, they considered grammar to be the basis of communication and thus felt the need to make it a primary and explicit focus of their work. Endo, for example, explained in his first interview that he regularly told his students that grammar was absolutely necessary for both accurate and fluent use of English. As we illustrate below, the teachers' observed practices reflected these beliefs about the centrality of explicit grammar teaching.

\section{Grammar Teaching Activities}

In terms of the activities the teachers utilized in teaching grammar, there was a pronounced preference for the presentation of grammar rather than for activities where the grammar was practised. Collectively, some $80 \%$ of the lessons observed were spent on teacher-led grammar presentations (in one case, Endo spent 35 minutes of the 40 available explaining grammar, while in another Tanaka's explanation took up 30 minutes of a lesson). Tanaka explained the prevalence of explanations in this manner:

It [the explanation] may be too long. However, in fact, I need to cover what other levels are doing for mid/end-of-term exams. ... To cover those, I cannot exceed 3 hours for one unit. For level 1 students, they cannot do exercises without explanation .... I cannot waste my time and should not let students sleep ... and I need to keep pace with other classes. That's why I give 
a lot of explanations but cannot do enough exercises. (Tanaka, Interview 2, 5 Dec 2010)

Tanaka's concerns about keeping up with his colleagues highlight a contextual factor in his approach to teaching grammar. This was also noted by Matsuda when he explained that "I select grammar to explain based on what's in the coursebooks, so as to keep pace with other teacher's classes" (Matsuda, Interview 2, 5 Dec 2010), which was important to do because all students in the same year did the same mid-term and final examinations. Endo also acknowledged that he gave long lectures on grammar, but, echoing Tanaka's comments, he said that it was inevitable due to the limited time available to cover the syllabus. He was hopeful, though, that during his explanations the students were engaged in thinking about grammar:

I do give lectures, but I try to let them think and use their brains while listening .... It is like a Socratic method or playing catch between teachers and students. So the role of the teacher is to throw why questions to students to let them discover the rules. (Endo, Interview 2, 5 Dec 2010)

The teachers also cited a lack of time as the reason why they did not employ communicative activities (e.g., involving pair work) in their lessons; for example, Endo said, "No, it's impossible to use such activities. I know they are absolutely necessary but physically impossible because time is limited" (Endo, Interview 2, 5 Dec 2010).

Matsuda gave students a little more time to work on exercises than the other two teachers. However, during the activities, he translated English into Japanese sentence-by-sentence, and checked the meaning of words and key grammar items. In justifying this approach, his views were that

we need to check the meanings of each sentence, to help those students who cannot get good grades, to help them keep up with the lessons. Otherwise, they will lose a sense of accomplishment .... We need to care for such students. (Matsuda, Interview 2, 5 Dec 2010)

A concern for helping the less able students was a strong theme in his account of why he focused explicitly on explaining grammar:

One of the features of a Japanese coursebook is that it has a lot of grammar items. When I think of the faces of the students 
who cannot do well in the exam, I feel I need to explain things to them. When I think about examinations, I cannot leave them stranded .... I must help them review so that they can recall what they learned before. (Matsuda, Interview 2, 5 Dec 2010)

\section{Analysing Grammar}

The detailed analysis of grammar was a key feature of the work of Endo and Tanaka. Because Matsuda was observed teaching grammar in the context of a reading lesson, he spent comparatively less time than the other two teachers talking about grammar in class but still explained grammar in detail after the reading work had been completed. Episode 1 illustrates how Tanaka approached the analysis of grammar:

\section{Episode 1: Presenting to-infinitive}

T: In the last lesson, I explained how to use to-infinitive in noun or adjective phrases. But today, what we will learn is for example ...

And then he writes He went to England on the blackboard.

T: This to shows what?

S: Direction.

T: Right. Mr. Nishimuro went to England.

Then he adds to study next to the sentence.

T: What we will learn today is this to. To plus a verb. What comes after to is a verb. What does this to mean?

S: In order to.

T: Right. This to refers to a goal. Because this to study modifies the whole sentence, we call this the adverbial usage of to-infinitive. (Tanaka, Observation 1, 5 Jul 2010)

In this extract, grammar is being presented through decontextualized sentences (i.e., individual sentences not part of a longer stretch of discourse). This was typical of the work of Tanaka and Endo and both teachers shared the belief that analysing grammar in this manner allowed students to learn it more effectively. For example, Endo explained that 
to obtain the knowledge of the grammar, students will get confused if there is a context.... In the beginning, students should only focus on the form and know why this is past tense or present tense. And once they understand, it's better to read the text and check how they are used. (Endo, Interview 2, 5 Dec 2010)

Such comments imply a belief that the form of grammar needs to be mastered before its use can be learned, a position which is at odds with the view that encountering grammar in context is beneficial to learning as it allows students to establish clear links between form and meaning.

Episode 1 also illustrates how Tanaka led the analysis of grammar by asking students a series of closed questions-this analysis was conducted orally and via teacher-class interaction. Endo's approach to grammar analysis reflected a similar approach, as Episode 2 shows:

Episode 2: Presenting present perfect

E: I'm sure you have learned present perfect in junior high school. What was the form?

Ss: Have plus a past participle.

He writes have (has) + p.p. on the blackboard.

E: And in junior high, you learned that the present perfect is used to mean things being done, result, experience, and continuity. But, it's not important to remember those things. But knowing the world of present perfect is important. Before we do that, what do you think about these two sentences, I finished lunch and I have finished lunch? What is the difference? Could you translate these?

Ss: One student answers-Watashi wa hirugohan wo tabeta.

E: Yes, in Japanese, we say them in the same way, but in English, there is a difference. An important thing is to grasp the image that native speakers have. The present progressive is like a movie and presents a sense of energy, the past tense is like a photograph. Then what's present perfect?

(He then explains that the present perfect tense indicates an image of $a p$ proaching to the present, and distributes a handout and reads it with students.) (Endo, Observation 2, 5 Dec 2010) 
Endo liked to compare structures and to make students aware of the way that native speakers of English interpreted the target structures (often, as in this case, using metaphors as part of his explanation). On the importance of comparing structures, Endo explained that

for example, in junior high schools, they don't teach the difference between will and be going to. In high schools, I expect students not only to know the rules as rules, but also I want them to know how native speakers grasp the images or the world of grammar. ... Because students do have basic knowledge of grammar, I want students to discover the rules using what they have got like in mathematics. (Endo, Interview 2, 5 Dec 2012)

Endo's comments echo those made earlier by Tanaka about encouraging students to discover rules, though as we see from the extract above Endo's approach to presenting grammar involved discovery that was highly teacher led (as opposed to forms of discovery grammar work where learners are deeply engaged in analyzing and discussing language and reaching their own conclusions-see, for example, Tomlinson, 2007).

\section{L1 and Terminology}

In the lessons observed, grammar teaching was strongly characterized by the use of the L1 and (particularly in the work of Tanaka and Endo) of grammatical terminology (the teachers used terminology in Japanese, not in English-for example, to-futeishi, for to-infinitive). Endo's view on the widespread use of the L1 in teaching grammar was that "It was too unnatural to use classroom English. It confuses students who are low in proficiency .... The most important goal in this lesson is to understand the logic of English grammar" (Endo, Interview 2, 5 Dec 2010).

Tanaka also justified his use of the L1 with reference to students' level and motivation:

It may depend on the students' level but for level 1 students, it's better to use Japanese, because they can understand it the most. Moreover, these lower level students hate English and do not study hard. Students tend to sleep in class or don't even open the coursebook .... To attract them to English, I must go off on tangents and tell interesting stories relating to the target grammatical points, but to do so, they won't understand if I use English. (Tanaka, Interview 2, 5 Dec 2010) 
Matsuda felt that using English in his reading classes was not relevant to the goal of enabling students to do well in reading comprehension tests: "The target skill of the lesson is to read English.... students feel no necessity to use English for instruction because it won't be on the exams. Their goal at this stage is to get good grades" (Matsuda, Interview 2, 5 Dec 2010).

Grammatical terminology was another salient feature of the classroom talk during Endo and Tanaka's lessons (see Episodes 1 and 2 above). Matsuda's use of terminology was less frequent but was nonetheless evident, as the next episode shows:

Episode 3: A participle construction

(After reading the text, checking the meanings of the passage and listening to the $\mathrm{CD}$, Matsuda introduced the target grammar.)

M: Look at line 10, Just lying around all day, it opens its cute eyes if it is patted, and begins to wave its flippers. What is this construction [i.e., lying around all day]?

Ss: A participle construction.

M: Yes, the subject is omitted, and this it refers to what?

Ss: A robotic seal.

M: That's right. So the subject of this clause is also a robotic seal. (Matsuda, Observation 2, 5 Nov 2010, p. 3)

The three teachers held varying perspectives on the value of terminology. Tanaka and Endo both agreed it was important for learners, but for different reasons. Tanaka's view was that "for level 1 students, I make them pay attention to the structure and usage of grammatical items because they don't even understand what adjectives are .... They should be taught thoroughly" (Tanaka, Interview 2, 5 Dec 2010). He believed that a knowledge of terminology was essential for lower level learners to understand grammar. Endo also valued the use of terminology, but he explained, "I use them [grammatical terms] to give students a sense of security. There are students who like terminology to remember grammatical items. Students can check if their knowledge of grammar is correct so that they can feel secure" (Endo, Interview 2, 5 Dec 2010). Endo was not suggesting that knowing terminology improves grammar learning; rather, he believed that students derive a kind of psychological reassurance from learning the terms. Matsuda's views 
about terminology were less positive than the other two teachers: "I don't think they need to understand terminology. Some may be useful for students who are good at English, or take entrance exams outside the school or who are interested in English. I know that most students struggle with those words" (Matsuda, Interview 2, 5 Dec 2010). Nonetheless, he did not avoid the use of terminology in his classes.

\section{Discussion}

Our first research question focused on the nature of teachers' practices in teaching grammar. Contemporary views of L2 learning (see, for example, Storch, 2010) recognize a role for explicit grammar work in the context of a broader communicative framework. Relative to this position, the grammar teaching practices highlighted in this study-characterized by discrete grammar lessons, extended decontextualized and metalinguistically rich teacher-led analysis conducted largely in the L1, with an emphasis on logic (e.g., equating grammar with mathematics) and limited opportunities for meaningful grammar use-would be considered somewhat traditional. It is not our goal here, though, to criticize the pedagogies of the three experienced teachers who participated in this study; rather, our aim is to understand factors that interactively shape the approach to grammar that the teachers adopted.

Our second research question was to ascertain which cognitions underpinned the teachers' practices. All three teachers shared the view that a knowledge of grammar was central to L2 learning and that grammar thus needed to be an important and explicit facet of the teaching of English. Such a view is not necessarily inconsistent with contemporary views of grammar in SLA research, though there was no evidence here that any of the teachers had been influenced by an awareness of such views; in fact, one noteworthy facet of the accounts they provided for their approaches to grammar was the absence of any reference to formal theory or methodological concepts in L2 teaching (which was also a feature of the teacher accounts of grammar teaching reported in Borg \& Burns, 2008, and Eisenstein-Ebsworth \& Schweers, 1997). The bases for the teachers' classroom practices seemed to be in fact largely experiential. One contributing factor here was their own histories as learners of English and it is highly likely that the way they were taught was not fundamentally different to their own practices today (see, for example, Nishino, 2011, who found that Japanese teachers said they had had few chances to experience communicative activities in English lessons when they were high school students). The experiential basis of how the 
teachers taught grammar was also informed by their professional experiences over many years in a system that has traditionally promoted formal grammar learning and by their accumulated knowledge of the students and the institutional context in which they work. One general conclusion from this study is that teachers' pedagogies had a very strong experiential basis, with very limited evidence that theoretical or methodological principles played a role in determining what the teachers did. We are not suggesting that the teachers lacked an awareness of such principles, but it is clear that in explaining the rationales for their pedagogical choices the teachers did not seek to justify their work in terms of theories of language learning and teaching.

In discussing the reasons for their approach to grammar, the teachers did articulate a number of beliefs. Some were specifically about language learning, such as that grammar is central to L2 learning, that grammar is best learned form first and out of context, and that a knowledge of terminology can support grammatical understanding. Many of the teachers' beliefs, though, related to learning more broadly. Thus, the teachers felt that learner motivation may be harmed if they have to struggle to understand the teacher (and for this reason the L1 was widely used). They also felt a duty to give lower level learners additional support so that they may experience a sense of achievement (and this is why lengthy grammatical explanations were provided). Effective rapport with students was also valued (and this was another reason for using the L1). A belief in learning through discovery was also cited to justify teacher-led whole class elicitation of grammar rules (as we noted earlier, though, this notion of discovery does not reflect what is typically implied in discussions of inductive grammar work-see, for example, Gollin, 1998). Overall, the teachers' general beliefs about students' well-being, motivation, and sense of achievement seemed to be at least as powerful an influence on how grammar was taught as specific beliefs about L2 grammar learning itself. Writing about the teaching of English in Japan, Aspinall (2006) also noted that the teachers were often concerned about the general well-being of their students rather than focusing solely on their progress as language learners. These findings remind us that in seeking to understand how teachers teach grammar, it is important to explore not just the views they hold about L2 learning but also their broader underlying, and sometimes more powerful (see Phipps \& Borg, 2009), beliefs about learning in general.

Studies of teachers' practices and cognitions must also take into account the effect that context has on mediating the relationship between what 
teachers believe and what they do, and this was the focus of our third research question. There is evidence in the literature that teachers' beliefs about L2 learning may sometimes be at odds with how they teach (for a recent review of this literature see Basturkmen, 2012) and the explanation often given for such mismatches is the constraining influence of the context, especially assessment (see, for example, Pahissa \& Tragant, 2009, who illustrate the impact of a high-stakes examination on grammar teaching in Spain).

In this study, the teachers considered test preparation important, but it did not emerge as a major constraint on what they did. The teachers felt, though, that the learners' low proficiency and motivation were powerful influences on how they approached grammar. Two other contextual factors that were influential were a lack of time and collective targets. Thus, the teachers felt they had limited time to cover the syllabus and also felt under pressure to cover the textbook at the pace needed to meet the targets agreed by all colleagues teaching any particular level. This combination of time and collective targets was cited by the teachers as one reason why so little classroom time was allocated to grammar practice or to any form of pair work or group work, even though the teachers acknowledged the value of communicative work. Rather, they prioritized the presentation and analysis of grammar as this was seen as the most direct and time-efficient way of promoting understanding. This finding reflects that of Sato and Kleinsasser (2004), in which teachers avoided using communicative activities even in oral communication lessons in order to "keep pace" with other classes. Our analysis of contextual factors here was limited to those within the teachers' school; the larger historical and socio-cultural context for education in Japan (e.g., decisions made at Ministry level) will also inevitably have had a bearing on what teachers do in the classroom.

Overall, then, our results add to existing evidence of the complex and multi-faceted nature of L2 grammar teaching. What emerges from this study is a portrait of how three high school teachers of English in Japan approached grammar, together with insights into the beliefs (about grammar, L2 learning, and education more broadly) and the contextual factors which, interactively, shaped the teachers' pedagogical choices.

\section{Conclusion}

In concluding this study, we acknowledge that the insights presented here have arisen from the analysis of a total of six lessons and six interviews involving three very experienced male Japanese teachers of English working in 
the same high school. We are not seeking to make more general claims about the teaching of grammar in Japanese high schools (although research noted earlier about the implementation of communicative language teaching in Japan does point to pedagogical practices which reflect those described here). Similarly, we are not arguing that the cognitions articulated by these teachers are in any way typical of the wider population of teachers of English in Japan. The value of this research lies in the qualitative insights it provides into what teachers actually do in their classrooms and into the manner in which teachers rationalize their practices. As noted earlier, in the last 15 years there has been increasing interest in exploratory case studies of this kind in the context of L2 grammar teaching, yet (in contrast with larger scale survey studies of teachers' attitudes and practices) specific analyses of teachers' practices and cognitions in the Japanese context remain limited. Much further qualitative research of this kind is needed as it can contribute to an understanding of the challenges and dilemmas teachers face in teaching grammar and, in particular, inform a critical analysis of the forces which may counter policies which seek to promote communicative language teaching more widely in Japanese high schools.

Three interlinked issues to emerge here appear to merit, we believe, further study in ways that extend beyond the specific research questions we have addressed. The first stems from the contrast between contemporary views of good practice in L2 grammar teaching and the pedagogies the teachers adopted here. Where do the beliefs underlying such pedagogies (such as the view that grammatical forms are best initially encountered out of context) come from? To what extent do teachers believe these pedagogies are effective and how do they make such judgements? Why are such instructional practices resilient despite efforts to make the teaching of English in Japanese high schools less grammar focused? The second issue (which may underlie the first) is the limited role that knowledge about L2 teaching played in teachers' rationales for their work. We recognize that experience will always be a major influence on what teachers do but argue that experience alone, particularly that which is not subject to critical reflection informed by propositional knowledge, may not necessarily promote productive pedagogy. Thus, what propositional knowledge about L2 grammar teaching do teachers hold and to what extent does this inform the pedagogical decisions teachers make? Finally, there was evidence here that teachers' general educational beliefs about keeping students interested and motivated were at least as powerful as their subject-specific beliefs about how to teach grammar. Thus, how do these different belief systems 
interact in influencing how teachers teach grammar? Insights into all these issues can enhance understandings of grammar teaching and contribute to teacher development not only in Japan but also in the field of L2 learning more generally.

\section{Acknowledgements}

We thank the teachers who participated in this study for their cooperation.

Masateru Nishimuro holds an MA TESOL degree from the University of Leeds and currently teaches English at Kwansei Gakuin Senior High School in Japan.

Simon Borg is a professor of TESOL at the University of Leeds. His interests are language teacher cognition, teacher education, grammar teaching, and teacher research.

\section{References}

Andrews, S. (2007). Teacher language awareness. Cambridge: Cambridge University Press.

Aspinall, R. W. (2006). Using the paradigm of 'small cultures' to explain policy failure in the case of foreign language education in Japan. Japan Forum, 18, 255-274.

Basturkmen, H. (2012). Review of research into the correspondence between language teachers' stated beliefs and practices. System, 40, 282-295.

Basturkmen, H., Loewen, S., \& Ellis, R. (2004). Teachers' stated beliefs about incidental focus on form and their classroom practices. Applied Linguistics, 25, 243-272.

Borg, S. (1998). Teachers' pedagogical systems and grammar teaching: A qualitative study. TESOL Quarterly, 32, 9-38.

Borg, S. (2001). Self-perception and practice in teaching grammar. ELT Journal, 55, 21-29.

Borg, S. (2003). Teacher cognition in language teaching: A review of research on what language teachers think, know, believe, and do. Language Teaching, 36, 81-109.

Borg, S. (2006). Teacher cognition and language education: Research and practice. London: Continuum.

Borg, S., \& Burns, A. (2008). Integrating grammar in adult TESOL classrooms. Applied Linguistics, 29, 456-482. 
Denscombe, M. (2002). Ground rules for good research. Buckingham, UK: Open University Press.

Dörnyei, Z. (2007). Research methods in applied linguistics. Oxford: Oxford University Press.

Duff, P. (2008). Case study research in applied linguistics. New York: Erlbaum.

Eisenstein-Ebsworth, M., \& Schweers, C. W. (1997). What researchers say and practitioners do: Perspectives on conscious grammar instruction in the ESL classroom. Applied Language Learning, 8, 237-260.

Ellis, R. (2006). Current issues in the teaching of grammar: An SLA perspective. TESOL Quarterly, 40, 83-107.

Ellis, R. (2008). The study of second language acquisition (2nd ed.). Oxford: Oxford University Press.

Farrell, T. S. C., \& Lim, P. C. P. (2005). Conceptions of grammar teaching: A case study of teachers' beliefs and classroom practices. TESL-EJ, 9(2), 1-13.

Gollin, J. (1998). Deductive vs. inductive language learning. ELT Journal, 52, 88-89.

Gorsuch, G. (2000). EFL educational policies and educational cultures: Influences on teachers' approval of communicative activities. TESOL Quarterly, 34, 675-710.

Gorsuch, G. (2001). Japanese EFL teachers' perceptions of communicative, audiolingual and yakudoku activities: The plan versus the reality. Education Policy Analysis Archives 9(10). Retrieved from http://epaa.asu.edu/ojs/article/view/339/465

Jean, G., \& Simard, D. (2011). Grammar teaching and learning in L2: Necessary, but boring? Foreign Language Annals, 44, 467-494.

Kanno, Y., \& Stuart, C. (2011). Learning to become a second language teacher: Identities-in-practice. The Modern Language Journal, 95, 236-252.

Kikuchi, K., \& Browne, C. (2009). English educational policy for high schools in Japan: Ideals vs. reality. RELC Journal, 40, 172-191.

Kim, E. J. (2011). An activity theory analysis of a teachers' experience. In K. E. Johnson \& P. R. Golombek (Eds.), Research on second language teacher education (pp. 225-238). London: Routledge.

Kuzborska, I. (2011). Links between teachers' beliefs and practices and research on reading. Reading in a Foreign Language, 23, 102-128. Retrieved from http:// nflrc.hawaii.edu/rfl/April2011/articles/kuzborska.pdf

Nassaji, H., \& Fotos, S. S. (2011). Teaching grammar in second language classrooms. London: Routledge.

Newby, P. (2010). Research methods for education. Harlow, UK: Pearson Education. 
Nishino, T. (2008). Communicative language teaching: An exploratory survey. JALT Journal, 30, 27-50.

Nishino, T. (2011). コミュニカティブ・アプローチに関する日本人高校英語教師の信条と実践 [Japanese high school teachers' beliefs and practices regarding communicative language teaching: An exploratory survey]. JALT Journal, 33, 131-155.

Nitta, R., \& Gardner, S. (2005). Consciousness-raising and practice in ELT coursebooks. ELT Journal, 59, 3-13.

Pahissa, I., \& Tragant, E. (2009). Grammar and the non-native secondary school teacher in Catalonia. Language Awareness, 18, 47-60.

Phipps, S., \& Borg, S. (2009). Exploring tensions between teachers' grammar teaching beliefs and practices. System, 37, 380-390.

Sakui, K. (2004). Wearing two pairs of shoes: Language teaching in Japan. ELT Journal, 58, 155-163.

Sakui, K. (2007). Classroom management in Japanese EFL classrooms. JALT Journal, 29, 41-58.

Sato, K., \& Kleinsasser, R. C. (2004). Beliefs, practices, and interactions of teachers in a Japanese high school English department. Teaching and Teacher Education, 20, 797-816.

Schulz, R. A. (1996). Focus on form in the foreign language classroom: Students' and teachers' views on error correction and the role of grammar. Foreign Language Annals, 29, 343-364.

Schulz, R. A. (2001). Cultural differences in student and teacher perceptions concerning the role of grammar instruction and corrective feedback. The Modern Language Journal, 85, 244-258.

Storch, N. (2010). Researching grammar. In B. Paltridge \& A. Phakiti (Eds.), Continuum companion to research methods in applied linguistics (pp. 205-221). London: Continuum.

Taguchi, N. (2005). The communicative approach in Japanese secondary schools: Teachers' perceptions and practice. The Language Teacher, 29(3), 3-12.

Tomlinson, B. (2007). Using form-focused discovery approaches. In S. Fotos \& H. Nassaji (Eds.), Form-focused instruction and teacher education (pp. 177-192). Oxford: Oxford University Press.

Underwood, P. R. (2012). Teacher beliefs and intentions regarding the instruction of English grammar under national curriculum reforms: A theory of planned behaviour perspective. Teaching and Teacher Education, 28, 911-925. 


\section{Appendix A}

\section{Pre-Observation Interview Questions}

Section 1: Background

- Age

- Qualifications

- Years of ELT experience

Section 2: Experience of learning/teaching grammar

1. How were you taught English/grammar when you were a student?

2. Was a particular approach to grammar promoted in your teacher training courses?

3. The school culture

- Does the school you work for promote any particular style of teaching (grammar)?

- Are there any restrictions on the kind of materials you use or on the content and organization of your lessons?

Section 3: General questions about grammar teaching and ELT

1. The role of grammar/formal instruction/ELT in general

- Do you think formal grammar instruction is essential to acquire English?

- Do you think there should be more formal study of grammar in your English course?

- Do you feel students receive enough grammar teaching?

- Do you think grammar teaching should be integrated with other skills teaching?

2. Decisions about what grammar to teach

- How do you decide what grammar items to teach?

- The guidelines? Exams? The textbooks? Students' expectation or others?

\section{Appendix B}

\section{Post-Observation Interview Questions}

The numbered headings were covered with all three teachers. However, the precise questions varied across the teachers depending on what was observed during the lessons. The questions below are from Endo's interview. 
1. The use of L1

- You used Japanese almost $100 \%$ during your lessons. Do you have any reasons for doing so? Or for not using English?

2. Presentation of grammar

- You presented grammar as it was presented in the coursebook without giving any context. Do you think grammar should be presented with/without context?

- What was your purpose of using handouts?

- You made your students use a dictionary. What was your purpose in relation to grammar teaching?

- You always presented two different sentences to get students to notice the different structures and the usages. Do you always do that?

3. The use of grammar terminology

- You often used grammar terminology when you were explaining grammar. Do you think it is necessary or useful?

- Although you told students that they don't need to memorize the terms, you wrote them on the blackboard. What was your intention?

4. Grammar practices

- You simply used the exercises from the coursebook. Do you sometimes add your original exercises?

- There were no communicative activities or pair/group activities. Do you think they are necessary for grammar teaching?

- Do you think students need more exercises?

5. The roles of teachers/students

- You spent 35 minutes giving a lecture, and 5 minutes for students to work on the exercises. What do you think of this allocation of time? What do you think the teacher's role is?

6. The use of materials

- You simply followed the coursebook. Do you feel obliged to use exactly what is written in the coursebook?

7. Integration of grammar and skills teaching

- You did not integrate any skills teaching. Do you think you should teach grammar separately or together with skills? 